https://doi.org/10.18485/iipe_60nam.2021.ch12

\title{
60TH ANNIVERSARY OF THE ESTABLISHMENT OF NON-ALIGNED MOVEMENT - INVITATION TO REASON, DIALOGUE AND COEXISTENCE
}

\author{
Živadin JOVANOVIĆ ${ }^{1}$
}

\begin{abstract}
Today, the Non-Alignment Movement (NAM) consists of 120 countries, which is two-thirds of the total number of members of the United Nations. It is indisputable that the NAM played a historically significant role in four basic directions of global development - in decolonisation, reducing the bloc division of the world, strengthening solidarity among developing countries (South-South), as well as in democratising international relations. Today, among the members of the NAM are countries with extremely dynamic economies such as India, Indonesia, South Africa, Nigeria, Angola, and among the observers are China and Brazil - the members of the BRICS. Several members and observers of the NAM are also members of the Group of 20 most economically developed countries in the world. Almost all major countries producing and exporting oil, gas and other important strategic raw materials from Africa, Asia and Latin America are in the NonAligned Movement. Despite the essential changes that occurred after the end of the Cold War, and which led to the cessation of the bloc confrontation and the establishment of a new post-bipolar world order, the role of the Non-Aligned Movement in achieving a more just world order has not ceased. On the contrary, its role has been deepened and intensified through the development of multilateral cooperation that should eliminate various types of threats and risks to international peace and security. Since more balanced economic and technological development, reducing the gap between rich and poor, eradicating misery, hunger and poverty are some of the most important goals of the Non-Aligned Movement, the Movement remains a significant factor in
\end{abstract}

\footnotetext{
${ }^{1}$ Former Minister of Foreign Affairs of the Federal Republic of Yugoslavia. E-mail: jovanovic.zivadin@gmail.com
} 
modern international relations and a place to articulate the needs and attitudes of humanity.

Key words: the Non-Alignment Movement, principles and goals, SouthSouth cooperation, contemporary international relations, Serbia.

\section{Introduction}

The founding Summit of the Non-Aligned Movement (NAM), held on 1-6 September 1961 in Belgrade, was an event of historical significance for the development of global international relations. The Summit was an expression of the deepest conviction that only peace, dialogue and coexistence have no alternative because a global catastrophe is not a rational option. According to Leo Mates, a well-known Yugoslav diplomat and director of the Institute for International Politics and Economics in Belgrade (IIPE), the summit in Belgrade was "certainly the most prominent gathering of statesmen ever held, not only in Belgrade but in recent history" (Mates, 1964-1965, pp. 465, etc.). It was a time of growing ideological and bloc confrontation, accelerated arms races, the multiplication of serious incidents in relations between the two most powerful world powers - the US and the USSR, the spread of crisis hotspots and great dangers of global conflict, including nuclear, with unforeseeable consequences for humanity. The atmosphere that preceded the Belgrade NAM Summit can be somewhat evoked by the reminder that five months before its holding, that is on 1 May 1961, an American U-2 spy plane was shot down over the territory of the USSR. The immediate consequence of that event was the cancellation of the meeting of the four great powers, which was supposed to take place in Paris, a few days after the incident with the downing of U-2. A much more serious consequence is the drastic deterioration of US-USSR relations, the acceleration of the arms race and the escalation of the Cold War. The summit was followed by the Cuban Missile Crisis, which threatened a direct US-Soviet nuclear conflict. Despite great breakthroughs in science and technology, the unjust system of global economic relations has generated a deepening economic and social chasm between the developed north and the underdeveloped south of the planet. Countries just freed from the colonial yoke gained political independence, but that was not enough to initiate more serious economic and social development and reduce economic dependence on the former colonial metropolises. Disparities between the low prices of raw materials at the disposal of the newly liberated countries and the high prices of industrial products, 
especially equipment, which had to be imported from the former metropolises, jeopardised the realisation of minimum expectations regarding the growth of living standards. Colonialism gave way to neocolonialism. However, despite the resistance of the colonial powers and their structures in the former colonies, the process of decolonisation continued and intensified. The division into military-political blocs NATO (1949) and the Warsaw Pact (1955), with the roles of protectors of opposing ideologies and systems of socio-economic order, threatened to divide and drag the whole world into confrontation, especially the newly liberated countries. In this atmosphere, the leaders of 29 countries in Asia and Africa, including the leaders of India, China and Japan, at a conference held in Bandung, Indonesia, from 18-24 April 1955, adopted five basic principles of mutual relations, as follows: 1 . Respect for sovereignty and territorial integrity; 2 . Mutual non-aggression; 3 . Noninterference in internal affairs; 4 . Equality and mutually beneficial cooperation; 5. Peaceful coexistence of countries of different socioeconomic arrangements. According to many politicians and authors, these principles are the basis of non-alignment policy (Petković, 1974; Mates, 1974, p. 12). The fact is that most of the countries participating in the Bandung Conference later joined the Non-Aligned Movement.

\section{Strengthening the role of the NAM since the founding Summit in Belgrade}

The leaders of Yugoslavia - Josip Broz Tito, India's - Jawaharlal Nehru and Egypt's - Gamal Abdel Nasser, met on 19 July 1956 in Brioni, where they adopted the famous 12-point Brioni Declaration. In the Declaration, the leaders emphasised the importance of the Bandung Conference. At the same time, they advocated peace, disarmament and the implementation of a policy of active peaceful coexistence, which could contribute to the peaceful settlement of disputes in Europe, the Middle East and the Far East. It is especially important that the leaders also advocated for providing assistance to underdeveloped countries. The Declaration in principle emphasised the position of non-alignment, i.e., non-compliance with any political bloc. The leaders also advocated for the admission of the People's Republic of China to the UN.

The Declaration states, among other things: "Peace cannot be achieved by division, but by striving for collective security on a global scale and expanding the area of freedom, as well as ending the 
domination of one country over another." The views of the participants in the Brioni meeting, although adopted 65 years ago, still sound relevant today. The value of these messages is especially confirmed by the challenges, behaviours and inconsistencies revealed by the Covid-19 pandemic and the new economic crisis.

The first NAM Summit in Belgrade has been prepared intensively for several years. In these preparations, in addition to India, Egypt and Indonesia, an important role was played by the Federal People's Republic of Yugoslavia, which enjoyed high respect and trust, among other things, for its unique contribution to the victory over Nazism and fascism in World War II. In April 1961, in a meeting between Presidents Tito and Nasser in Cairo, based on previous consultations with the leaders of other countries, it was agreed that the First NAM Summit would be held in Belgrade the same year. Somewhat later, a preparatory conference was held from 5 to 12 June 1961 in Cairo, with the participation of representatives of the countries that accepted the summit invitation at which the organisation and topics of the Summit were determined. Among other things, the Declaration underlines that: "Peace cannot be achieved by division, but by striving for collective security on a global scale and expanding the area of freedom, as well as ending the domination of one country over another." (Mates, 1976; Piršl, 1977, p. 9).

The preparatory conference was held in Cairo in June, the same year at which the organisation and topics of the Summit were determined. From the beginning of the preparations, it was clear that the NAM did not intend to be a passive observer of the development and competition of great powers, but an active participant in the fight for peace, security, equality and economic development. Later, it will be publicly emphasised that the responsibility for the future of humanity cannot be in the hands of only a few states, no matter how big and powerful they may be. This rejected the division into blocks, as well as the creation of the so-called Third block. The first NAM summit in Belgrade was attended by 25 countries as full members and 3 countries as observers, as well as representatives of 38 liberation and progressive movements. The central global topics of the Belgrade NAM Conference were establishing international peace and security, overcoming uneven economic development and improving mutual economic cooperation of nonaligned countries.

After an extensive discussion, by consensus, as a rule of decision in the NAM, three documents were adopted: the Belgrade Declaration of 
Heads of State and Government; A statement on the danger of war and an Appeal for peace, as well as two letters with identical content, one to the President of the Council of Ministers of the USSR, Nikita Khrushchev, and the other to the President of the US, John F. Kennedy. The main attention of the participants in the debate as well as in the Declaration of the Summit is devoted to the following issues: 1. Respect for the right to self-determination, the fight against imperialism and the liquidation of colonialism; 2. Respect for sovereignty and territorial integrity, noninterference in the internal affairs of other states; 3 . Struggle to end racial discrimination and apartheid policies; 4. General and complete disarmament, Ban on nuclear tests, the problem of foreign military bases; 5. Active peaceful coexistence between countries with different socioeconomic arrangements; 6 . The role and structure of the United Nations and the implementation of its resolutions. The host of the summit, Yugoslav President Josip Broz Tito, in his address to the Summit participants, pointed out that the Non-Aligned Movement was an independent factor in international relations, thus establishing a relationship with the blocs, which sought to put at least parts of the US under their influence. This attitude would later evolve into an even clearer warning that the NAM cannot be treated as anyone's reserve or a foothold for narrower geopolitical goals. Tito also pointed out that the Movement was the conscience of humanity, which made it known that the NAM also had a moral dimension because it fights for truth, peace and justice. In the preparations for the Summit, the criteria for membership in the NAM were crystallised: 1 . Independent policy based on active peaceful coexistence; 2 . Support for national independence movements; 3 . The country is not a member of any military-political alliance aimed at confrontation; 4 . There are no agreements with the great powers that serve the confrontation; 5 . There are no foreign military bases on its territory. In the preparations and at the Summit itself, the following goals of the NAM were crystallised: the struggle for peace, security and independence; decolonisation, the abolition of racial discrimination and apartheid; the economic and social development through South-South cooperation and building a just world economic order; struggle against imperialism and neo-colonialism; combating all forms of foreign interference, domination and hegemony; fight against all forms of foreign aggression and occupation; UN support; codification and respect for international law. The Summit accepted the principled position that nonalignment does not mean passivity, even neutrality in international relations, but an active relationship in finding principled and fair solutions 
to all problems, as well as decisive support to developing countries through coordinated activities.

\section{Institutionalisation and previous results of the NAM}

In the previous period, the NAM achieved its set goals through cooperation within the Movement, especially through South-South cooperation, as well as through coordinated action throughout the United Nations system. In the latter case, the NAM acted primarily within the General Assembly, ECOSOC, UNCTAD, and G-77. As the NAM does not have a rigid organisational structure, high-level summits are held every three years, on the principle of rotation of chairpersons. As a rule, ministerial meetings are held before each summit, as well as every year during the regular sessions of the UN General Assembly. Expert meetings are held as needed. Initiatives of non-aligned countries are most often initiated by representatives of the country holding the presidency for a three-year period, and more recently by a troika consisting of the current, previous and future chairmen. Coordination is conducted through the Coordination Bureau at the level of Permanent Representatives to the UN in New York. The Special Council coordinates the activities of non-aligned states that are members of the UN Security Council. Today, the NAM has 120 members, which represents about two-thirds of the total number of UN members or over $55 \%$ of the world's population. China, as the most populous nation and the second strongest economy in the world, as well as Brazil, the largest country in South America and one of the five BRICS members, have observer status, which also speaks of the attractive strength of the NAM. The rapid growth of the NAM members was a consequence of the decolonisation process that took place from the Second World War onwards. The NAM was the most deserving international factor that colonialism as a deviation of civilisation handed down to history. Colonial countries and peoples, who for centuries have been victims of foreign domination and exploitation, by participating in the NAM have won freedom and the opportunity to participate equally in international relations. The strengthening of the role of the NAM was also influenced by the so-called G-77 countries made up mostly of non-aligned countries. A significant number of non-aligned countries are also part of the G-20 Group, which has become increasingly important since the outbreak of the global economic and financial crisis in 2008. From the first summit in Belgrade in 1961 to the last summit held in Baku in 2019, the NAM contributed to the democratisation of the work of the General 
Assembly and the entire UN system. The movement contributed to resolving local and regional disputes and crises, to the fight against racism and the end of the apartheid system (South Africa, Namibia). The NAM has a significant impact on raising awareness of the need to establish equal relations based on respect for the principles of sovereign equality, sovereignty, including economic sovereignty, territorial integrity, and non-interference in internal affairs.

\section{South-South cooperation}

South-South cooperation was one of the NAM's priorities. It greatly reduced the dependence of a number of non-aligned countries on former colonial powers and developed countries in general, as well as the danger of using economic levers to interfere in internal affairs. Yugoslavia, as one of the more developed members of the NAM, was one of the most desirable partners in that cooperation. It had relatively developed technologies in industry and construction, as well as in food production (seeds), which was of special importance for a large number of nonaligned countries. Among other things, Yugoslavia opened the door wide to the training of personnel from non-aligned countries, which were used extensively by many non-aligned countries. On the other hand, these cadres have contributed to a significant improvement in the understanding and cooperation of many non-aligned countries with Yugoslavia. The advantage of Yugoslavia was that it never interfered in the internal affairs of the partner countries, regardless of the wide involvement in all forms of cooperation from defence to the education of journalists and scientists. Yugoslav construction and design companies were among the best in the world in terms of capacities and quality of works and equipment, as well as in terms of prices. They built hydroelectric power plants, highways, airports, dams, ports, conference and trade centres, stadiums, hospitals, irrigation systems, complete cities. The "Jira Pjura" project in Peru worth one billion dollars, the contractor "Energoprojekt" from Belgrade, provided water to the desert area and enabled food production. In Algeria, a Yugoslav construction operative rebuilt the city of Oran after a catastrophic earthquake. In Tunisia, Yugoslav companies have installed water reservoirs, in Libya ports, in Angola Lubango Airport and oil concessions (NIS), in Zambia a conference centre, a hydroelectric power plant, as well as thousands of kilometres of roads of various categories. Also, the results of Yugoslav economic cooperation in Ghana, Guinea, Nigeria, Egypt, Tunisia, Kuwait, 
Qatar, Iraq, Ethiopia, Uganda, and Sao Tome and Principe are significant. The relations of friendship and cooperation have led to exceptional results and the realisation of common commercial interests. We estimate that the relations between Serbia and non-aligned countries could even be improved today, as well as the cooperation between the South and the South in general, starting from the respect of mutual interests. The NAM arose as a factor in overcoming bloc divisions and overcoming the dramatic danger of the outbreak of nuclear war. The NAM was an important organised group that recognised this great danger, raised the voice of reason and demanded that the confrontation move to dialogue, concessions and a reduction of mistrust. The NAM has made a great contribution to easing tensions and eliminating the danger of conflict. Yugoslavia made a great contribution to the initiation and operation of a group of non-aligned and neutral European countries that played an important role in the process of creating the CSCE (OSCE). Yugoslavia played the role of a "bridge" in connecting Europe and the NAM. All these facts represent an extremely important legacy that can contribute to a better foreign policy positioning of Serbia, but also a more responsible attitude towards historical trends, which often represent a signpost for future relations.

\section{The NAM in Contemporary International Relations}

Europe and the world still face similar problems that the NAM faced at the time of its constitution, only at a higher level. The arms race has reached unprecedented proportions, with the world spending over \$ 1.5 trillion on arms annually. The confrontation and mistrust of the great powers raise concerns about future developments. Unilateralism, protectionism and economic sanctions are so widespread that one can speak of an ongoing economic war. Militarisation has affected large parts of the economy, infrastructure, education, the media, all the way to the system of political decision-making. Legal regulations in the field of arms control are in a kind of crisis either due to the cancellation of previously concluded agreements or due to the expiration of their validity. Mass military exercises often have a provocative character. Interventionism, expansionism and the so-called coloured revolutions threaten to destabilise entire regions. The pace of militarisation of the universe is worrying. The influence of universal organisations for security and cooperation, such as the UN and the OSCE, has been marginalised. There are more and more widespread analyses that indicate that Europe and 
the world have entered a new cold war. On the other hand, the process of global warming continues, and the Covid-19 pandemic, in addition to a mass threat to human health, is causing a new crisis in economic relations. All this is more fraught with unpredictable dangers, as the entire system of the multinational neoliberal corporate system has entered a crisis, and there are no solutions on the horizon. The socio-economic gap has been frighteningly deepened both globally and within individual countries. We are witnessing the militarisation of many areas of the economy, infrastructure, politics, education and the media. Today, there are more foreign military bases in Europe than at the time when the Cold War was at its peak. Expenditures on weapons are higher than ever. The militaryindustrial complex, through its lobbies in state institutions, is asking for a further increase in the costs of armament. This situation threatens to take control. Valid arms control agreements are being violated and cancelled. All this is followed by the deployment of new weapon systems where they never existed. Also, there is more and more threatening incitement to war accompanied by massive military exercises ("Defender 20" and "Defender 21"), which are more provocative than in the era when the Cold War was at its zenith.

The military-industrial complex is persistently engaged in the production of the enemies of Europe and the Indo-Pacific, that is, the Far East, in order to offer them protection. The ongoing trade, economic and propaganda wars represent a revision of the historical results of the two world wars. This situation warns of the danger of even more dangerous types of warfare and revision of history. In such conditions, no one can and must be relaxed, frivolous and lulled by the naive belief that someone else, more responsible, will find a solution for peace, stability and progress. Today, a call to reason and a contribution to peace are equally needed. The voice of reason, peace and coexistence, the voice of the original NAM is even more needed today than it was 60 years ago. We believe that such a voice and invitation will again start from Belgrade this jubilee year. I believe that the danger of uncontrolled conflict, including the danger of the use of nuclear weapons, is no less today than in 1961 when the founding summit of the NAM was held in Belgrade. On the global factors - the US, Russia, China, the greatest responsibility is to find a mode for renewing mutual dialogue and partnership as soon as possible, which should be a possible easing of tensions and renewal of negotiations on arms control and refraining from any provocative activities. An integral part of such a course should be the acceptance of obligations to support the United Nations and strengthen respect for the basic principles of international law, whose 
further erosion threatens the spread of the virus of arbitrariness and chaos in international relations. If we recall that one of the main goals of the NAM was to reduce the socio-economic gap between the group of rich and most poor countries, it can be concluded that this problem is far more acute today than it was in 1961. So, the needs for the NAM are even greater today than in the past. But, it should be said that there are factors that do not suit that, whose interest is a kind of pacification of the NAM. These factors sow doubts, divisions, and even direct conflicts within the NAM. These factors "play the card" of weakening any resistance to the policy of domination. These and similar actions should be identified in a timely manner so that actions can be taken that would contribute to a higher degree of freedom and independence, i.e., more equitable international relations. Adapting to profound changes in the distribution of global power, the struggle for equality, principles, partnership and mutually beneficial cooperation is one of the directions of modern international relations. The other direction is the pursuit of preserving privileges and hegemony, accelerating the arms race and increasing the danger of global conflict. We believe that one of the priorities, strategic goals of the NAM in the coming period should be to support the process of multi-polarization and build a new world order based on equality, sovereignty and territorial integrity of all countries. The multi-polarization of global relations provides a chance for their democratisation. Multi-polarization alone is not an automatic guarantee and protection against attempts at domination. More centres do not mean that democratic international relations and equality are ensured. However, more centres of power open up space for democratisation that is easier to secure. This space should be filled and used for equality and independence. The NAM is the factor on which this new quality depends - democratic international relations based on equality, sovereignty and shared responsibility for a more humane and prosperous world.

\section{Serbia's position in the NAM}

Serbia inherits the great achievements of the NAM, not only because Belgrade is the place of the First Founding Conference of the Movement, but primarily because it has participated in a wide and intensive cooperation of the NAM for a long time. Serbia, as the successor of Yugoslavia, is recognized as a reliable, constructive partner, both in political and economic cooperation, transfer of technology and knowledge, education, security and defence, media development and many other areas. By far the largest number of bearers of cooperation between 
Yugoslavia and the NAM came from Serbia. Even today, Serbia is unreservedly accepted as a priority partner of the NAM, which enjoys a great reputation and trust as a partner that consistently follows the original principles of the NAM - respect for sovereignty and territorial integrity, non-interference in internal affairs, active peaceful coexistence and cooperation for mutual benefit. Serbia is a desirable partner as a "bridge" of cooperation and understanding between the NAM and Europe and the NAM and third countries. Since Serbia has started reindustrialisation and is gradually entering the fourth industrial revolution, it can be an even more desirable partner for the NAM. On the other hand, the NAM members have huge natural and human, market resources, energy, raw materials, including strategic mines. Serbia will need all that on the path of development, modernisation and far wider access to the international market. One of the key principles of the NAM is respect for sovereignty and territorial integrity, the fight against terrorism and separatism. That is why Serbia has so far enjoyed and still enjoys understanding and the widest support in protecting its own sovereignty and territorial integrity when it comes to resolving the final status of the province of Kosovo and Metohija on the basis of UN Security Council Resolution 1244. It is certain that Serbia can count on even broader and stronger support for the NAM, especially within the UN system and in key bodies such as the General Assembly, the Security Council, UNESCO and other branches of the UN system. Due to all that, it would be necessary for the competent institutions to seriously consider the possibility of returning Serbia to full membership in the NAM instead of the current observer status. Serbia's full membership in the NAM would bring significant benefits to Serbia in the political, security, economic and other fields and would not be in conflict with the status of Serbia's candidate for EU membership, which, it seems, will last a long time. The current political circumstances in Europe and the world indicate that the mood within the EU for the expansion of membership is constantly declining. The EU has other and far more significant challenges and priorities. Therefore, Serbia's full membership in the EU is not realistic in the foreseeable future.

\section{Conclusions:}

\section{Perception of possible priorities and actions of the NAM}

From the historical experience and international activities of the NAM so far, certain conclusions and predictions could be reported. Namely, the NAM today consists of 120 countries, which is two thirds of the total 
number of members of the United Nations. Hence, it cannot be disputed that the Non-Aligned Movement continues to play a significant role in the development of international relations. This is all the more so because its historical role in the process of decolonisation, reducing the political division of the world, strengthening solidarity among developing countries (South - South), as well as in achieving a fairer world order has not stopped but has deepened and intensified through the development of multilateral cooperation to eliminate various types of threats and risks to international peace and security. Given that more balanced economic and technological development, reducing the gap between rich and poor, eradicating misery, hunger and poverty are some of the most important goals of the NAM, the Movement remains a significant factor in modern international relations and a place to articulate the needs and attitudes of humanity. According to our perception, in the current circumstances, the NAM could take appropriate actions related to: control and coordination of treatment of the Covid-19 pandemic; prevention of future pandemics and specific situations; participation in the reform of world and regional health systems; participation in food security system and the implementation of a plan to eliminate world hunger by 2040; establishing an urgent dialogue between the five permanent members of the UN Security Council to address global issues such as the fight against pandemics, global warming, nuclear weapons control, global economic recovery, etc .; initiating the reform of the international economic order; building a multi-polar world order as a condition for substantial democratisation; providing urgent assistance to the poorest countries to rehabilitate health and hunger problems, to write off debts; encouraging the development of multilateralism; execution of assumed international legal obligations and implementation of UN decisions. At the same time, the NAM should contribute to refraining from activities that increase global tensions, and in that sense take measures to strengthen trust at the global level.

\section{References}

Mates, Leo. (1964-65). Beogradska konferencija neangažovanih, Godišnjak grada Beograda. Beograd. XI-XII: 465-492.

Mates, Leo. (1974). Koegzistencija, Zagreb, Školska knjiga.

Mates, Leo. (1976). Međunarodni odnosi socijalističke Jugoslavije, Beograd, Nolit. Petković, Ranko. (1974). Teorijski pojmovi nesvrstanosti, Beograd: Rad,. Piršl, Emil. (1977). Nesvrstani, Zagreb. Spektar. 